\title{
The Use of Neutrophil/Lymphocyte Ratio (Nlr), Platelet/Lymphocyte Ratio (Plr), and Mean Platelet Volume (Mpv) As Inflammatory Biomarkers in the Prognosis of Patients with Early-Stage Colorectal Adenocarcinoma
}

\author{
A. Murat BUYRUK ${ }^{1}$, Seher Nazli KAZAZ ${ }^{2}$, Ilhan OZTOP $^{2}$, Huseyin S. SEMIZ ${ }^{2}$, \\ Utku OFLAZOGLU ${ }^{3}$, Isil SOMALI ${ }^{2}$ \\ ${ }^{1}$ Ege University Faculty of Medicine, Department of Gastroenterology \\ ${ }^{2}$ Dokuz Eylul University Faculty of Medicine, Department of Medical Oncology \\ ${ }^{3}$ Izmir Ataturk Training and Research Hospital, Department of Medical Oncology, Izmir, TURKEY
}

\begin{abstract}
Colorectal cancer (CRC) represents the most prevalent cancer of the gastrointestinal system in adults. Despite long-term survival rates achieved by early resection and adjuvant therapies, relapse is a significant problem for those patients. The present study aims to investigate the possibility of using neutrophil/lymphocyte ratio (NLR), platelet/lymphocyte ratio (PLR), and mean platelet volume (MPV) as biomarkers for postoperative relapse in patients with CRC. We retrospectively analyzed 188 non-metastatic CRC patients followed up and treated at Dokuz Eylül University, Faculty of Medicine Hospital, Medical Oncology Clinic. We recorded demographic, laboratory and histopathological data from patient files and we calculated NLR, PLR and MPV, which were recorded as preoperative, postoperative and relapse values. This study classified patients into two groups: relapsed and relapse-free patients. Twenty-five patients (13.3\%) developed a relapse during the follow-up period. The relapsed group had a higher NLR prior to tumor resection compared to the relapse-free patients, whereas PLR and MPV were not high. Despite the absence of any significant change in NLR or MPV after tumor resection, PLR displayed an upwards trend. At the time of relapse, CEA and MPV increased as PLR fell (compared to the postoperative period). The relapse-free group exhibited a significant decrease in CEA and MPV after tumor resection, and other parameters did not change. Comparing the results based on disease stages, stage III patients had significantly higher MPV levels than the stage II. NLR, MPV and PLR may help physicians identify prognosis after tumor resection in patients with CRC.
\end{abstract}

Keywords: Biomarker, Colorectal cancer, Inflammation, Prognosis

ÖZET

Nötrofil /Lenfosit Oranı (NLR), Trombosit /Lenfosit Oranı (PLR) ve Ortalama Trombosit Hacmi'nin (MPV) Erken Evre Kolorektal Adenokarsinomlu Hastaların Prognozunda İnflamatuar Biomarker Olarak Kullanımı

Kolorektal kanser (KRK), yetişkinlerde gastrointestinal sistemin en sık görülen kanseridir. Erken evrede cerrahi rezeksiyon ve adjuvan tedavilerle uzun süreli sağkalımlar elde edilmekle birlikte bu hastaların bir kısmında nüks önemli bir problemdir. Bu çalısmada nötrofil/ lenfosit oranı (NLR), trombosit/lenfosit oranı (PLR) ve ortalama trombosit hacmi (MPV)'nin KRK tanilı hastalarda postoperatif nüks izleminde biyomarker olarak kullanılabilirliğinin araştıılması amaçlandı. Dokuz Eylül Üniversitesi Tıp Fakültesi Hastanesi Tıbbi Onkoloji kliniğinde KRK tanısı ile takip ve tedavi edilen non-metastatik toplam 188 hasta retrospektif olarak değerlendirildi. Hastalara ait dosya kayıtlarından demografik, laboratuar ve histopatolojik verileri kaydedildi. Labotaruvar değerlerinden ve NLR, PLR ve MPV hesaplandı ve bu değerler operasyon öncesi, operasyon sonrası ve nüks anındaki değerler olarak kaydedildi. Çalışmada hastalar nüks gelişen ve nüks gelişmeyen olarak 2 gruba ayrıldı. Hastaların 25'inde (\%13.3) izlemde nüks görüldü. Nüks gelişen grupta nüks gelişmeyen gruba göre tümör rezeksiyonu öncesi dönemde NLR daha yüksek bulunurken, PLR ve MPV yüksek bulunmadı. Bu grupta tümör rezeksiyonu sonrası NLR ve MPV'de anlamlı değişiklik izlenmezken, PLR değerinin artma eğilimi gösterdiği izlendi. Nüks anında ise (post-operatif döneme göre) CEA, MPV değerlerinin arttı̆̆ı, PLR değerinin ise düştüğü gözlendi. 
Nüks izlenmeyen grupta ise tümör rezeksiyonu sonrasında CEA ve MPV'de anlamlı azalma izlenirken, diğer parametrelerde değişiklik saptanmadı. Sonuçlar hastalık evrelerine göre değerlendirildiğinde, evre III hastalarda evre II'ye göre tanı anında MPV değerinin yüksek olması istatistiksel olarak anlamlı bulundu. Kolorektal kanserli hastalarda NLR, MPV ve PLR tümör rezeksiyonu sonrası prognozun belirlenmesinde yardımcı olabilir.

Anahtar Kelimeler: Biomarker, Kolorektal kancer, Inflamasyon, Prognoz

\section{INTRODUCTION}

Colorectal cancer is the third most common type of cancer worldwide. Every year, more than one million people are diagnosed with colorectal cancer. ${ }^{1}$ It ranks second among cancer-caused deaths, following the lung cancer. The prognosis of CRC is closely related to the stage of disease at the time of diagnosis. Early-stage patients exhibit a 5-year survival rate over $90 \%$, which remains around $10 \%$ for metastatic patients. ${ }^{2}$

Relapse is a crucial problem for patients with colorectal cancer. Approximately $50 \%$ of the patients treated due to early-stage CRC develop a relapse in the follow-up period. ${ }^{3}$ Therefore, timely diagnosis of a relapse in the early-stage patients is important in terms of potential subsequent curative therapies. Alongside radiological and endoscopic examinations, tumor markers are also commonly used both for the diagnosis and through the follow-up of CRC. Carcinoembryonic antigen (CEA), carbohydrate antigen 19-9 (CA 19-9) and $\alpha$-fetoprotein (AFP) are primary tumor markers to check. ${ }^{4,5} \mathrm{~A}$ study on CEA, the most commonly used biochemical marker to follow-up relapses, reported that a CEA level exceeding $5 \mathrm{ng} / \mathrm{ml}$ has a $75-80 \%$ positive predictive value for relapsing. Around $70 \%$ of relapsed patients exhibited increased CEA levels. ${ }^{6}$ Moreover, there are other studies on laboratory parameters including hemoglobin levels and liver function tests (LFT) to detect relapse, with no significant relation found. ${ }^{7,8}$

Inflammation is the most essential and critical stage in cancer progression. Continuation of the inflammatory process results in tumor cell proliferation, increased angiogenesis, and inhibited apoptosis. ${ }^{9}$ One may observe changes in blood components such as neutrophils, lymphocytes, and monocytes in the systemic inflammatory response. Therefore, NLR and PLR are potentially consid- ered to indicate prognosis in inflammation-related malignancies. High preoperative NLR levels in stomach, pancreatic, non-small-cell lung cancer and ovarian cancer have been interpreted to indicate a poor prognostic factor. ${ }^{10-14} \mathrm{~A}$ study including 235 patients with ovarian cancer reported that PLR might be considered a new prognostic indicator for that cancer. ${ }^{15}$

MPV is an indicator of the platelet volume. Mean platelet volume also reflects inflammation, and it has been demonstrated to increase in chronic inflammatory diseases. ${ }^{16}$

Studies on patients with stomach cancer and nonsmall-cell lung cancer showed that MPV might serve as a prognostic indicator of overall survival. ${ }^{17,18}$

High MPV, NLR and PLR values in patients recently diagnosed with CRC may indicate inflammation in the colon and an increased cytokine level. A relevant study reported significantly higher preoperative MPV, NLR and PLR in patients with CRC compared to the controls, which decreased significantly in the postoperative period. ${ }^{19}$

There are a limited number of studies on the potential use of NLR, PLR and MPV as prognostic factors in the follow-up of colorectal cancer. The present study aimed to investigate the role of NLR, PRL and MPV as biomarkers in the postoperative relapse follow-up of patients with colorectal cancer.

\section{PATIENTS and METHODS}

In total, 1.020 patients diagnosed with colorectal adenocarcinoma at Dokuz Eylül University, Faculty of Medicine Hospital, Medical Oncology Clinic from 2005 to 2015 were scanned to be included in the study. A total of 832 patients who were ex- 
cluded from the study received any medication that might increase serum neutrophil and leukocyte levels, had a concomitant infection, hematologic, renal or rheumatic diseases and other types of cancer, were metastatic at the time of diagnosis, or their data were not fully available. 188 non-metastatic and early-stage patients with fully available data were included in the study. The Local Ethics Committee approved the study.

We retrospectively scanned the patient files to record the following data: demographic characteristics such as age, gender, and educational background; disease-related information such as history of disease, location of the primary tumor, date of operation, type of operation, tumor pathology (histology, stage, grade, vascular invasion, lymphatic invasion, perineural invasion, tumor budding); and laboratory parameters such as the number of neutrophils, lymphocytes and platelets in preoperativepostoperative periods and at the time of relapse if any, as well as MPV and CEA values. We used the TNM staging recommended by AJCC (American Joint Committee on Cancer Recommendations) for this purpose. Preoperative data included those measured during the colonoscopic examination, postoperative data included those measured in two weeks after the operation, and relapse data included those recorded at the time of relapse. NLR and PLR were calculated by dividing the neutrophil value with the lymphocyte value (neutrophil/ lymphocyte) and the platelet value with the lymphocyte value (platelet/lymphocyte), respectively. CEA, MPV, NLR, and PLR values were recorded for each patient as preoperative, postoperative and at the time of relapse. Throughout this process, changes in said parameters were separately analyzed for each patient.

\section{Statistical Analysis}

All statistical analyses were performed with SPSS 15.0 (Chicago, Illinois) package software. ChiSquare Test, Kruskal-Wallis Test, Mann-WhitneyU Test, and Wilcoxon Signed-Rank Test were used to analyze the data. $\mathrm{p}<0.05$ was taken to indicate statistical significance.

\begin{tabular}{|c|c|}
\hline Characteristics & N (\%) \\
\hline \multicolumn{2}{|c|}{ Age (years) (Median \pm Std. Deviation) } \\
\hline Median & $62.25 \pm 11.868$ \\
\hline Range & $33-86$ \\
\hline \multicolumn{2}{|l|}{ Gender } \\
\hline Male & $113(60.1)$ \\
\hline Female & $75(39.9)$ \\
\hline \multicolumn{2}{|l|}{ Tumor location } \\
\hline Rectum & $69(36.7)$ \\
\hline Sigmoid Colon & $49(26.1)$ \\
\hline Right Colon & 70 \\
\hline \multicolumn{2}{|l|}{ TNM Staging } \\
\hline I & $20(11.7)$ \\
\hline$\|$ & $81(47.4)$ \\
\hline III & $70(40.9)$ \\
\hline \multicolumn{2}{|l|}{ Histological Grade } \\
\hline G1 & $110(64)$ \\
\hline G2 & $44(25.5)$ \\
\hline G3 & $18(10.5)$ \\
\hline \multicolumn{2}{|l|}{ Vascular invasion } \\
\hline Yes & $26(13.8)$ \\
\hline No & $162(86.2)$ \\
\hline \multicolumn{2}{|l|}{ Lymphatic invasion } \\
\hline Yes & $63(33.5)$ \\
\hline No & $125(66.5)$ \\
\hline \multicolumn{2}{|l|}{ Perineural invasion } \\
\hline Yes & $31(16.5)$ \\
\hline No & $157(83.5)$ \\
\hline \multicolumn{2}{|l|}{ Tumor budding } \\
\hline Yes & $98(52.1)$ \\
\hline No & $90(47.9)$ \\
\hline \multicolumn{2}{|l|}{ Recurrence } \\
\hline Yes & 25 (13.3) \\
\hline No & $163(86.7)$ \\
\hline \multicolumn{2}{|l|}{ Trombosis } \\
\hline Yes & $13(6.9)$ \\
\hline No & $175(93.1)$ \\
\hline \multicolumn{2}{|c|}{ Adjuvant Chemotherapy } \\
\hline Yes & $156(82.97)$ \\
\hline No & $27(14.36)$ \\
\hline Unknown & $5(2.65)$ \\
\hline Exitus & $2(1.06)$ \\
\hline
\end{tabular}

\section{RESULTS}

\section{Demographic Characteristics:}

Of 188 patients included in the study, 113 (60.1\%) were male and $75(39.9 \%)$ were female. Patients' mean age was $62.25 \pm 11.87$ years (33-86 years). Regarding tumor location, 70 patients (37.2\%) had a tumor in the right colon, $69(36.7 \%)$ in the 
International Journal of Hematology and Oncology

Table 2. A comparison of preoperative and postoperative PLT, PLR, NLR, MPV, MCV, MCHC, and CEA values

\begin{tabular}{|llll}
\hline Parameters & $\begin{array}{l}\text { Preoperative } \\
\text { (Mean } \pm \text { SD) }\end{array}$ & $\begin{array}{l}\text { Postoperative } \\
\text { (Mean } \pm \text { SD) }\end{array}$ & p-value \\
\hline PLT $\left(\times 10^{3} / \mu \mathrm{L}\right)$ & $292.4 \pm 88.6$ & $295.9 \pm 98.4$ & 0.05 \\
MPV (fL) & $8.2 \pm 1.18$ & $8.06 \pm 1.06$ & 0.001 \\
PLR & $163.06 \pm 84.07$ & $193.35 \pm 112.25$ & 0.001 \\
NLR & $3.16 \pm 2.65$ & $3.5 \pm 7.74$ & 0.869 \\
MCV (fL) & $82.15 \pm 8.1$ & $82.94 \pm 6.82$ & 0.059 \\
MCHC $(\mathrm{g} / \mathrm{dL})$ & $33.22 \pm 1.47$ & $33.44 \pm 3.04$ & 0.433 \\
CEA $(\mathrm{ng} / \mathrm{mL})$ & $13.51 \pm 28.82$ & $3.22 \pm 4.31$ & 0.000
\end{tabular}

SD: Standart Deviation, PLT: Platelet count, MPV: Mean platelet volume; PLR: Platelet/lymphocyte ratio, NLR: Neutrophi//ymphocyte ratio, MCV: Mean corpuscular volume, MCHC: Mean corpuscular hemoglobin concantration, CEA: Carcinoembryonic antigen.

rectum, and $49(26.1 \%)$ in the sigmoid colon. We grouped the patients as follows, based on the stage of disease at the time of diagnosis: 20 patients $(11.7 \%)$ were stage I, $81(47.7 \%)$ stage II, and 70 (40.9\%) stage III. A pathological examination revealed that 110 patients $(64.0 \%)$ had a well-differentiated tumor while $44(25.5 \%)$ exhibited moderately-differentiated, and $18(10.5 \%)$ presented poorly-differentiated tumors. 26 patients $(13.8 \%)$ were vascular invasion (+), 63 (33.5\%) lymphatic invasion (+), and 31 (16.5) neural invasion (+). 98 patients $(52.1 \%)$ had the tumor budding phenomenon (Table 1).

\section{Sites of Relapse:}

The present study classified patients into two groups: relapsed and relapse-free patients. Twentyfive patients (13.3\%) developed a relapse during the follow-up period. Lung (6 patients, 24.0\%) and liver (6 patients, $24.0 \%$ ) were the most common locations of relapse. Other locations included colon, rectum, pericardium, peritoneum, brain, and bone tissue, respectively. Five of six patients with a relapse at the lung had a primary tumor in the rectum, whereas four of six patients with a relapse in the liver had a primary tumor in the sigmoid colon.

\section{CEA Levels:}

A comparison of preoperative and postoperative CEA levels of all patients revealed a significant decrease after tumor resection (mean: $13.51 \mathrm{ng} /$ $\mathrm{ml}$ preop. And mean: $3.22 \mathrm{ng} / \mathrm{ml}$ postoperative, $\mathrm{p}<$ 0.001) (Table 2). Having evaluated the results separately for relapsed and relapse-free groups, both groups presented a significant decrease in CEA levels after tumor resection (preop. mean: $7.51 \mathrm{ng} /$ $\mathrm{ml}$ and postoperative mean: $3.05 \mathrm{ng} / \mathrm{ml}$ for the relapsed group, $\mathrm{p}=0.003 ; 14.15 \pm 31.5$ and $3.29 \pm 4.45$

\begin{tabular}{|c|c|c|c|}
\hline Parameters & $\begin{array}{l}\text { Postoperative } \\
\text { (mean } \pm \text { SD) }\end{array}$ & $\begin{array}{l}\text { Relapse } \\
\text { (mean } \pm S D \text { ) }\end{array}$ & p-value \\
\hline PLT (x10³/uL) & $280.7 \pm 65.5$ & $229.1 \pm 69.8$ & 0.05 \\
\hline MPV (fL) & $7.80 \pm 0.72$ & $7.99 \pm 1.02$ & 0.37 \\
\hline PLR & $216.07 \pm 101.65$ & $158.57 \pm 59.85$ & 0.05 \\
\hline NLR & $3.14 \pm 2.06$ & $3.11 \pm 2.07$ & 0.372 \\
\hline MCV (fL) & $83.90 \pm 6.47$ & $87.4 \pm 7.86$ & 0.029 \\
\hline $\mathrm{MCHC}(\mathrm{g} / \mathrm{dL})$ & $33.35 \pm 0.83$ & $33.4 \pm 1.01$ & 1.0 \\
\hline CEA (ng/mL) & $2.81 \pm 4.25$ & $3.1 \pm 2.05$ & 0.042 \\
\hline
\end{tabular}




\begin{tabular}{|c|c|c|c|}
\hline Parameters & Relapse & $\begin{array}{l}\text { Preoperative } \\
\text { (Mean rank) }\end{array}$ & p-value \\
\hline \multirow[t]{2}{*}{ 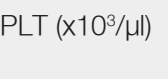 } & No & 83.12 & 0.120 \\
\hline & Yes & 99.98 & \\
\hline \multirow[t]{2}{*}{ PLR } & No & 82.31 & 0.079 \\
\hline & Yes & 101.23 & \\
\hline \multirow[t]{2}{*}{ NLR } & No & 82.37 & 0.041 \\
\hline & Yes & 104.54 & \\
\hline \multirow[t]{2}{*}{ MPV (fL) } & No & 86.80 & 0.396 \\
\hline & Yes & 77.60 & \\
\hline \multirow[t]{2}{*}{ MCV (fL) } & No & 83.92 & 0.302 \\
\hline & Yes & 95.10 & \\
\hline \multirow[t]{2}{*}{$\mathrm{MCHC}(\mathrm{g} / \mathrm{dL})$} & No & 84.76 & 0.627 \\
\hline & Yes & 90.02 & \\
\hline \multirow[t]{2}{*}{ CEA (ng/dL) } & No & 48.36 & 0.586 \\
\hline & Yes & 52.79 & \\
\hline \multicolumn{4}{|c|}{$\begin{array}{l}\text { SD: Standart Deviation, PLT: Platelet count, MPV: Mean platelet } \\
\text { volume; PLR: Platelet/lymphocyte ratio, NLR: Neutrophil/lym- } \\
\text { phocyte ratio, MCV: Mean corpuscular volume, MCHC: Mean } \\
\text { corpuscular hemoglobin concantration, CEA: Carcinoembryonic } \\
\text { antigen. }\end{array}$} \\
\hline
\end{tabular}

for the relapse-free group, $p=0.007)$. We observed that CEA level increased significantly in the relapsed group compared to the postoperative period (postoperative $2.81 \pm 4.24786,3.10 \pm 2.0504$ at the time of relapse, $\mathrm{p}=0.042$ ) (Table 3 ).

\section{MPV Levels:}

An evaluation of the results regarding MPV revealed a significant decrease in the postoperative MPV compared to the preoperative level (preoperative mean: $8.2 \mathrm{fl}$ and postoperative mean: $8.06 \mathrm{fl}$, $\mathrm{p}=0.001$ ) (Table 2). When the results are separately analyzed for relapsed and relapse-free groups, the latter exhibited significantly decreased MPV levels compared to the former (preoperative 8.19 \pm 1.17 , and postoperative $8.08 \pm 1.09, \mathrm{p}=0.007$ ) The decrease in the relapsed group was not significant (preoperative $8.00 \pm 0.71$, and postoperative $7.8 \pm 0.72, p=0.079)$. Although the MPV level at the time of relapse increased in the relapsed group compared to the postoperative level, it was not significant (postoperative $7.80 \pm 0.72,7.99 \pm 1.02$ at the time of relapse, $\mathrm{p}=0.37$ ) (Table 3 ).

\section{NLR Results:}

No significant difference was observed between preoperative and postoperative NLR values $(\mathrm{p}=$ 0.869) (Table 2). Having evaluated the results separately for relapsed and relapse-free groups, none of them presented a significant difference in preoperative and postoperative NLR levels $(3.77 \pm 2.46$ and $3.14 \pm 2.02$ for the relapsed, respectively, $\mathrm{p}=$ $0.361 ; 3.11 \pm 2.8$ and $3.62 \pm 8.70$ for the relapsefree, respectively, $\mathrm{p}=0.606$ ). No significant difference was observed between the postoperative NLR level and the NLR at the time of relapse in the relapsed group $(3.14 \pm 2.06$ and $3.11 \pm 2.07$, respectively, $\mathrm{p}=0.372)($ Table 3$)$.

\section{PLR Results:}

An evaluation of the results in terms of PLR showed a significantly increased postoperative PLR compared to the preoperative period (163.06 \pm 84.07 and $193.35 \pm 112.25 ; \mathrm{p}=0.001$ ) (Table 2). We analyzed the results separately for the relapsed and relapse-free groups and found no significant difference between preoperative and postoperative PLR values; however, the relapsed group exhibited a tendency towards increased PLR in the postoperative period (preoperative 178.39 \pm 78.12 and postoperative $216.59 \pm 99.54, \mathrm{p}=0.097)$. We observed that the PLR level at the time of relapse decreased significantly in the relapsed group compared to the postoperative level (postop. $216.07 \pm$ $101.65,158.57 \pm 59.85$ at the time of relapse, $\mathrm{p}=$ $0.05)$ (Table 3).

\section{Comparison of preoperative biomarkers with re- spect to relapse condition}

Comparing preoperative measurement values, we found a significant difference between the relapsed and relapse-free groups only in NLR values. The relapsed group had a higher preop. NLR (NLR: 104.54) than the relapse-free group (NLR: 82.37) $(\mathrm{p}=0.041)$. Despite the high PLR level exhibited by the relapsed group, the difference was not significant (Table 4). 


\begin{tabular}{|c|c|c|c|}
\hline \multirow[t]{2}{*}{ Characteristics } & \multicolumn{2}{|c|}{ Recurrence [n (\%)] } & \multirow[t]{2}{*}{ p-value } \\
\hline & Yes & No & \\
\hline \multicolumn{4}{|l|}{ Gender } \\
\hline Male & $16(15.5)$ & $87(84.5)$ & \multirow[t]{2}{*}{0,826} \\
\hline Female & $9(13)$ & $60(87.0)$ & \\
\hline \multicolumn{4}{|l|}{ TNM } \\
\hline Stage 1 & $3(15)$ & $17(85)$ & \multirow[t]{3}{*}{0.831} \\
\hline Stage 2 & $10(12.3)$ & $71(87.7)$ & \\
\hline Stage 3 & $11(15.7)$ & 59 (84.3) & \\
\hline \multicolumn{4}{|l|}{ Vascular invasion } \\
\hline Yes & $8(34.8)$ & 15 (62.2) & \multirow[t]{2}{*}{0.007} \\
\hline No & $17(11.4)$ & $132(88.6)$ & \\
\hline \multicolumn{4}{|c|}{ Lymphatic invasion } \\
\hline Yes & $6(11.1)$ & $48(88.9)$ & \multirow[t]{2}{*}{0.488} \\
\hline No & $19(16.1)$ & 99 (83.9) & \\
\hline \multicolumn{4}{|c|}{ Perineural invasion } \\
\hline Yes & 7 (26.9) & $19(73.1)$ & \multirow[t]{2}{*}{0.068} \\
\hline No & $18(12.3)$ & $128(87.7)$ & \\
\hline \multicolumn{4}{|l|}{ Tumor budding } \\
\hline Yes & $10(11.9)$ & $74(88.1)$ & \multirow[t]{2}{*}{0.391} \\
\hline No & $15(17.0)$ & $73(83.0)$ & \\
\hline \multicolumn{4}{|l|}{ Lymph node } \\
\hline Yes & $9(16.1)$ & $47(83.9)$ & \multirow[t]{2}{*}{0.818} \\
\hline No & $16(13.8)$ & $100(86.2)$ & \\
\hline \multicolumn{4}{|l|}{ Grade } \\
\hline 1 & $2(11.1)$ & $16(88.9)$ & \multirow[t]{3}{*}{0.872} \\
\hline 2 & 6 (13.6) & $38(86.4)$ & \\
\hline 3 & 17 (15.5) & $93(84.5)$ & \\
\hline
\end{tabular}

\section{Comparison of preoperative biomarkers with re- spect to staging}

A comparison of preop. levels with respect to staging revealed a significant difference for MPV only. Stage III patients (MPV: $108.53 \mathrm{fL}$ ) had a higher preoperative MPV than the stage II (MPV: 80.94 $\mathrm{fL})$, which was significant $(\mathrm{p}=0.004)$.

\section{Factors Affecting Relapse}

As regards the disease characteristics of relapse factors, a significant relation was detected between vascular invasion and relapse $(\mathrm{p}<0.05)$, while there was no significant relation between relapse and gender, lymphatic invasion, neural invasion, and tumor budding ( $\mathrm{p}>0.05)$ (Table 5).

An evaluation of relapse factors with respect to biomarkers indicated a high preop. NLR for the relapsed group with no postop. MPV decrease and PLR showed a tendency to increase. At the time of relapse, however, CEA and MPV rose and PLR fell (compared to the postoperative period) (Table 4).

\section{DISCUSSION}

The present study, which investigates the patients followed up and treated for colorectal cancer, found a relapse in $13.3 \%$ of the patients in the followup period. The relapsed group had a higher NLR prior to tumor resection compared to the relapsefree patients. Despite the absence of any significant change in NLR or MPV after tumor resection, PLR displayed an upwards trend. At the time of relapse, CEA and MPV increased, whereas PLR fell. The relapse-free group exhibited a significant decrease in CEA and MPV after tumor resection.

There are studies conducted with various biomarkers to identify prognosis and foresee a potential relapse of colorectal cancer. The studies on CEA represent a larger portion of the body of research in this context. ${ }^{20}$ On the other hand, there are fewer studies on MPV, NLR and PLR. The present study has investigated the role of NLR, PLR and MPV in foreseeing a potential relapse alongside their roles as biomarkers in early-stage CRC patients. Unlike previous studies, we included the non-metastatic patients at the time of diagnosis. We also analyzed the CEA level, and we consider the present study important as it is the first one to examine the correlation between CEA and aforementioned parameters, aiming to foresee a potential relapse.

MPV is an indicator of the platelet volume. Mean platelet volume also reflects inflammation, and it has been demonstrated to increase in chronic inflammatory diseases. ${ }^{16}$ In addition, high MPV levels constitute an independent risk factor for hypertension and myocardial infarction and are an indicator of poor prognosis for cardiovascular diseases. ${ }^{21,22}$ Studies on patients with stomach, hepatocellular and endometrial cancers reported higher preop. MPV levels than controls. ${ }^{23-25}$ Among the studies examining the prognostic value of MPV in patients with CRC, a study on operated patients with CRC reported a higher MPV level for those patients compared to the control group, which fell significantly after tumor resection, and this decrease was associated with the reduced tumor burden. ${ }^{19}$ Another study carried out a preopera- 
tive assessment for metastatic and non-metastatic patients, reporting higher MPV values for the former. The same study also found that, among metastatic subjects included, bevacizumab therapy was more beneficial for those with a lower MPV in terms of progression-free survival (HR: 0.41). ${ }^{26} \mathrm{In}$ our study, which included non-metastatic patients only, we expected a higher preoperative MPV for relapse-free patients than the relapsed in line with previous studies but we could not detect a significant difference. However, we observed that MVP fell after the operation and displayed a tendency to increase at the time of relapse. Likewise, at the time of diagnosis, stage III patients exhibited a higher MPV than the stage II patients. Our findings support the view that changes in MPV might be associated with the tumor burden.

Considered to be associated with systemic inflammation, NLR has been examined in the context of various cancers - stomach, ovarian and non-smallcell lung cancer particularly - and a high preoperative NLR has been reported to indicate a poor prognosis. ${ }^{10,13,14}$ Other studies investigating the prognostic value of NLR in patients with CRC also report a high preoperative NLR to be a negative prognostic factor. However, one should note that those studies assume different cut-off values for NLR. Among them, a study conducted with 823 patients took the cut-off value for NLR as 2.1 and stated that a high preoperative NLR was a poor prognostic factor particularly for the advancedstage patients. ${ }^{27}$ In a meta-analysis evaluating a total of 7,741 patients with CRC, the cut-off value was assumed as 5 for preoperative NLR, and the study concluded that patients with a pre-treatment NLR level higher than 5 also presented a high CEA level (which were correlated) and tumor burden, and those patients received fewer benefits from the neo-adjuvant therapy. ${ }^{28}$ We did not set a cutoff value for NLR as part of the present study; we compared the relapsed and relapse-free patient groups and found a higher preoperative NLR value in the former. Our findings suggest that a higher preoperative NLR value might be considered a poor prognostic factor for the patients recently diagnosed with CRC.

There are available studies reporting that PLR, just as NLR, can be used as a prognostic indicator for patients with CRC. A study conducted with 543 patients with early-stage CRC took the PLR cutoff value as 295 and found that a high preoperative PLR level is a prognostic factor with adverse effects on relapse-free survival and overall survival. ${ }^{29}$ Another study carried out with a similar patient group set the cut-off value for PLR at 157.8 and concluded that higher values were prognostic factors for disease-free survival and overall survival; the same study also reported a significant relationship between increased PLR level and mortality. ${ }^{30}$ Although the present study also detected a higher preoperative PLR in the relapsed group compared to the relapse-free, the difference remained under the threshold of significance. Interestingly, the present study detected that PLR fell at the time of relapse, contrary to the literature. In our view, this might be due to a relative decrease at the time of relapse, associated with PLR's tendency to increase in the postoperative period.

A study conducted a combined analysis of MPV, NLR and PLR on a total of 144 patients with CRC. The study assumed the following cut-off values: 2.02 for NLR (sensitivity: $86 \%$, specificity: $84 \%$ ), 135 for PLR (sensitivity: 70\%, specificity: 90\%) and $8.25 \mathrm{fl}$ for MPV (sensitivity: 54\%, specificity: $76 \%$ ). It suggested that high preoperative levels of those parameters constituted a negative prognostic factor and reported a significant decrease after tumor resection, accompanied by a reduced CEA. ${ }^{19}$ Likewise, the present study also detected, after tumor resection, a significant decrease in the whole patient group, whereas the decrease in MPV was limited to the relapse-free group. On the other hand, despite the absence of any significant change in NLR, PLR value displayed an upwards trend.

Unlike other studies, we included relapsed patients as well, and attempted to reveal the factors affecting the relapse phenomenon. In this context, we observed a high preop. NLR for the relapsed group with no postop. MPV decrease and PLR showed a tendency to increase. At the time of relapse, however, CEA and MPV rose and PLR dropped. Although the relapsed group exhibited a significantly reduced CEA particularly in the postoperative period, this was not the case for MPV, and this supports the usability of MPV as a prognostic factor. We were unable to perform a roc curve analysis or 
set cut-off values due to the relatively low number of relapsed patients part of our study.

In conclusion, this is a single-centered and retrospective study; therefore, a selection bias cannot be fully excluded. However, our data demonstrate that a high preoperative NLR and slightly reduced postoperative MPV are important for prognosis and relapse, and the high levels of CEA and MPV are striking at the time of relapse. Particularly the fact that the postoperative decrease in MPV observed in the relapsed group is less than the level exhibited by the relapse-free group may serve as a predictor of the microscopic residual disease. More comprehensive studies will shed further light on the role of those parameters.

\section{REFERENCES}

1. Parkin DM, Bray F, Ferlay J, Pisani P. Global cancer statistics, 2002. CA Cancer J Clin 55: 74-108, 2005.

2. Levin B, Lieberman DA, McFarland B, et al. Screening and surveillance for the early detection of colorectal cancer and adenomatous polyps. CA Cancer J Clin 58:130-160, 2008.

3. Boyle P, Ferlay J. Cancer incidence and mortality in Europe, 2004. Ann Oncol 16: 481-8, 2005

4. Li J, Liu Y, Xu JH, et al. Expression of hepatocyte growth factor and c-Met is characteristic of $\alpha$-fetoprotein-producing colorectal adenocarcinoma: A report of three cases. Oncol Lett 11: 731-734, 2016.

5. Stiksma J, Grootendorst DC, van der Linden PW. CA 19-9 as a marker in addition to CEA to monitor colorectal cancer. Clin Colorectal Cancer 2014;13:239-244.

6. Moertel CG, Fleming TR, Macdonald JS, et al. An evaluation of the carcinoembryonic antigen (CEA) test for monitoring patients with resected colon cancer. JAMA 270: 943-947, 1993.

7. Peethambaram $\mathrm{P}$, Weiss $\mathrm{M}$, Loprinzi $\mathrm{CL}$, et al. An evaluation of postoperative follow-up tests in colon cancer patients treated for cure. Oncology 54: 287-292, 1997.

8. Goldberg RM, Fleming TR, Tangen CM, et al. Surgery for recurrent colon cancer: strategies for identifying resectable recurrence and success rates after resection. Ann Intern Med. 129: 27-35, 1998.

9. Cendan JC, Behrns KE. Associated neoplastic disease in inflammatory bowel disease. Surg Clin North Am 87: 659-672, 2007.

10. Hu ZD, Huang YL, Qin BD, et al. Prognostic value of neutrophil to lymphocyte ratio for gastric cancer. Ann Transl Med 3: 50, 2015.
11. An X, Ding PR, Li YH, et al. Elevated neutrophil to lymphocyte ratio predicts survival in advanced pancreatic cancer. Biomarkers 15: 516-522, 2010.

12. Daniel K, Maya G, Maya IS, et al. Pretreatment neutrophil-tolymphocyte ratio in metastatic castration-resistant prostate cancer patients treated with ketoconazole: association with outcome and predictive nomogram. Oncologist 17: 15081514, 2012

13. Sarraf KM, Belcher E, Raevsky E, et al. Neutrophil/lymphocyte ratio and its association with survival after complete resection in non-small cell lung cancer. J Thorac Cardiovasc Surg 137: 425-428, 2009.

14. Cho H, Hur HW, Kim SW, et al. Pre-treatment neutrophil to lymphocyte ratio is elevated in epithelial ovarian cancer and predicts survival after treatment. Cancer Immunol Immunother 58: 15-23, 2009.

15. Asher V, Lee J, Innamaa A, Bali A. Preoperative platelet lymphocyte ratio as an independent prognostic marker in ovarian cancer. Clin Transl Oncol 13: 499-503, 2011.

16. Thompson CB, Jakubowski JA. The pathophysiology and clinical relevance of platelet heterogeneity. Blood 72: 1-8, 1988.

17. Lian L, Xia YY, Zhou C, et al. Mean platelet volume predicts chemotherapy response and prognosis in patients with unresectable gastric cancer. Oncol Lett 10: 3419-3424, 2015.

18. Inagaki N, Kibata K, Tamaki T, et al. Prognostic impact of the mean platelet volume/platelet count ratio in terms of survival in advanced non-small cell lung cancer. Lung Cancer 83: 97101,2014

19. Kilincalp S, Coban S, Akinci H, et al. Neutrophil/lymphocyte ratio, platelet/lymphocyte ratio, and mean platelet volume as potential biomarkers for early detection and monitoring of colorectal adenocarcinoma. Eur J Cancer Prev 24: 328-333, 2015.

20. Tartter PI, Slater G, Gelernt I, Aufses AH Jr. Screening for liver metastases from colorectal cancer with carcinoembryonic antigen and alkaline phosphatase. Ann Surg 193: 357-360, 1981.

21. Altinbas S, Togrul C, Orhan A, et al. Increased MPV is not a significant predictor for preeclampsia during pregnancy. $J$ Clin Lab Anal 26: 403-406, 2012.

22. Bath $\mathrm{P}$, Algert C, Chapman N, et al. Association of mean platelet volume with risk of stroke among 3134 individuals with history of cerebrovascular disease. Stroke 35: 622-626, 2004.

23. Kilincalp S, Ekiz F, Basar O, et al. Mean platelet volume could be possible biomarker in early diagnosis and monitoring of gastric cancer. Platelets 25: 592-594, 2014.

24. Kurt M, Onal IK, Sayilir AY, et al. The role of mean platelet volume in the diagnosis of hepatocellular carcinoma in patients with chronic liver disease. Hepatogastroenterology 59: 15801582, 2012

25. Oge T, T Yalcin O, Ozalp SS, Isikci T. Platelet volume as a parameter for platelet activation in patients with endometrial cancer. J Obstet Gynaecol 33: 301-304, 2013. 
26. Tuncel T, Ozgun A, Emirzeoglu L, et al. Mean platelet volume as a prognostic marker in metastatic colorectal cancer patients treated with bevacizumab-combined chemotherapy. Asian Pac J Cancer Prev 15: 6421-6423, 2014.

27. Kubo H, Murayama Y, Arita T, et al. The Prognostic Value of Preoperative Neutrophil-to-Lymphocyte Ratio in Colorectal Cancer. World J Surg 1-7, 2016.

28. Tsai PL, Su WJ, Leung WH, et al. Neutrophil-lymphocyte ratio and CEA level as prognostic and predictive factors in colorectal cancer. J Cancer Res Ther 12: 582-589, 2016.

29. Choi WJ, Cleghorn MC, Jiang H, et al. Preoperative Neutrophil-to-Lymphocyte Ratio is a Better Prognostic Serum Biomarker than Platelet-to-Lymphocyte Ratio in Patients Undergoing Resection for Nonmetastatic Colorectal Cancer. Ann Surg Oncol 22: 603-613, 2015.

30. You J, Zhu GQ, Xie L, et al. Preoperative platelet to lymphocyte ratio is a valuable prognostic biomarker in patients with colorectal cancer. Oncotarget 18: 516-527, 2016.

\section{Correspondence:}

Dr. Seher Nazli KAZAZ

Dokuz Eylul Universitesi Tip Fakultesi

Tibbi Onkoloji Anabilim Dali

Balcova, IZMIR / TURKEY

Tel/Fax: (+90-232) 4124801

e-mail: drnazli@gmail.com 